UCRL-ID-113275

\title{
The Use of Post Detonation Analysis of Stable Isotope Ratios to Determine the Type and Production Process of the Explosive Involved
}

\author{
Raymond R. McGuire \\ J Division
}

Carol A. Velsko

Nuclear Chemistry Division

Chet G. Lee

Energetic Materials Section

Chemistry Department

Ellen Raber

J Division

Lawrence Livermore National Laboratory

March 5, 1993

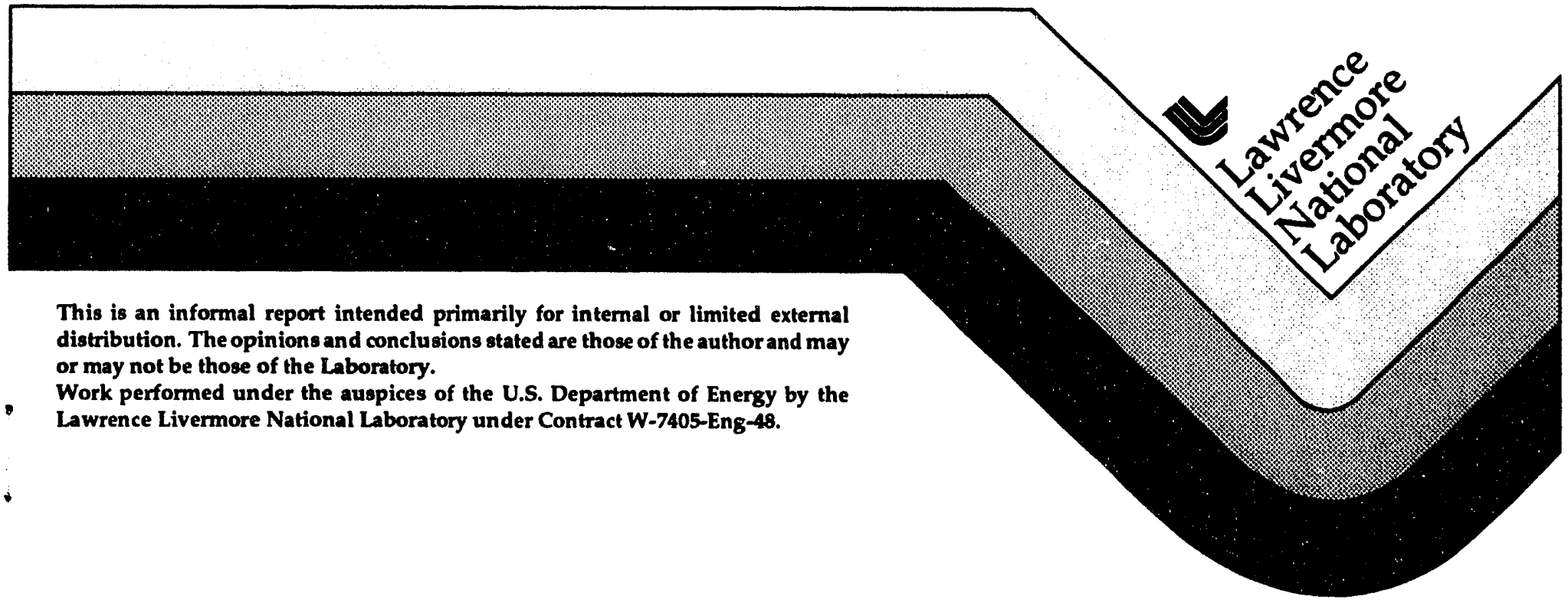




\section{DISCLAIMER}

This document was prepared as an account of work sponsored by an agency of the United States Government. Neither the United States Government nor the University of California nor any of their employees, makes any warranty, express or implied, or assumes any legal liability or responsibility for the accuracy, completeness, or usefulness of any information, apparatus, product, or process disclosed, or represents that its use would not infringe privately own rights. Reference herein to any specific commercial products, process, or service by trade name, trademark, manufacturer, or otherwise, does not necessarily constitute or imply its endorsement, recommendation, or favoring by the United States Government or the University of California. The views and opinions of authors expressed herein do not necessarily state or reflect those of the United States Government or the University of Califomia, and shall not be used for advertising or product endorsemenli purposes.

This report has been reproducerd directly from the best available copy.

Available to DOE and DOE contractors from the Office of Scientific and Technical Information

P.O. Box 62, Oak Ridge, TN 37831

Prices available from (615) 576-8401, FTS 626-8401

Available to the public from the

National Technical Information Service

U.S. Department of Commerce

5285 Port Royal Rd.

Springfield, VA 22161 


\title{
THE USE OF POST DETONATION ANALYSIS OF STABLE ISOTOPE RATIOS TO DETERMINE THE TYPE AND PRODUCTION PROCESS OF THE EXPLOSIVE INVOLVED
}

\author{
Raymond R. McGuire \\ J Division \\ Carol A. Velsko \\ Nuclear Chemistry Division \\ Chet G. Lee \\ Energetic Materials Section \\ Chemistry Department \\ Ellen Raber \\ J Division \\ Lawrence Livermore National Laboratory
}

March 5, 1993 


\title{
THE USE OF POST DETONATION ANALYSIS OF STABLE ISOTOPE RATIOS TO DETERMINE THE TYPE AND PRODUCTION PROCESS OF THE EXPLOSIVE INVOLVED
}

\author{
Raymond R. McGuire \\ J Division \\ Carol A. Velsko \\ Nuclear Chemistry Division \\ Chet G. Lee \\ Energetic Materials Section \\ Chemistry Department \\ Ellen Raber \\ J Division \\ Lawrence Livermore National Laboratory
}

\section{INTRODUCTION}

The determination of the ratios of stable isotopes in geologic materials is a standard technique used to determine the origin of the sample. Stable isotopes are fractionated in the environment by physical, chemical, and biological processes. These include:

- Processes in which the rates are mass dependent, such as diffusion of ions or molecules and ultrafiltration;

- Isotopic exchange reactions involving redistribution (at equilibrium, the rates of the forward and backward isotopic exchange reactions are the same. This is true for both common and rare isotopes. An example of an isotopic equilibrium would be water vapor in isotopic equilibrium with liquid water);

- Chemical kinetic isotope fractionations produced by unidirectional reactions where the rates are mass dependent (an example of such fractionation is the rapid freezing of water to ice. In general, the lighter isotope will react faster); and

- Biological processes such as sulfate reduction by bacteria as well as the degradation kinetics associated with the formation of fossil fuels. 
The method of expressing the deviation of isotopic ratios from a naturally occurring standard is the "delta" scale where delta $(\delta)$ is the deviation in parts per thousand.

$$
\text { Delta }(\delta)=1,000 \times(\text { ratio of sample } / \text { ratio of standard }-1)
$$

Figures 1 and 2 show the normal " $\delta$ " values of ${ }^{13} \mathrm{C} /{ }^{12} \mathrm{C}$ and ${ }^{2} \mathrm{H} /{ }^{1} \mathrm{H}$ for some naturally occurring substances.

Because water is made up of hydrogen and oxygen, ${ }^{2} \mathrm{H}$ (deuterium) and ${ }^{18} \mathrm{O}$ are integrated into any formulation process involving water. The naturally occurring differences in isotopic ratios are a function of several factors, including altitude, latitude, continental effects (heavier isotope content decreases with increasing distance from the coast), and the season of the year. The reference material for expressing the " $\delta$ " value for ${ }^{2} \mathrm{H}$ and ${ }^{18} \mathrm{O}$ is "Standard Mean Ocean Water (SMOW)." The " $\delta$ " values; i.e., ${ }^{2} \mathrm{H} /{ }^{1} \mathrm{H}$ and ${ }^{18} \mathrm{O} /{ }^{16} \mathrm{O}$, have been used to successfully determine the origin of ground water, the identification of water masses, flow path analyses, assessment of rock-water interactions, and indirect water age determinations.

The ${ }^{13} \mathrm{C}$ is a stable isotope that occurs in all carbon bearing materials. The abundance of ${ }^{13} \mathrm{C}$ in a carbon sample is referenced to an "average marine

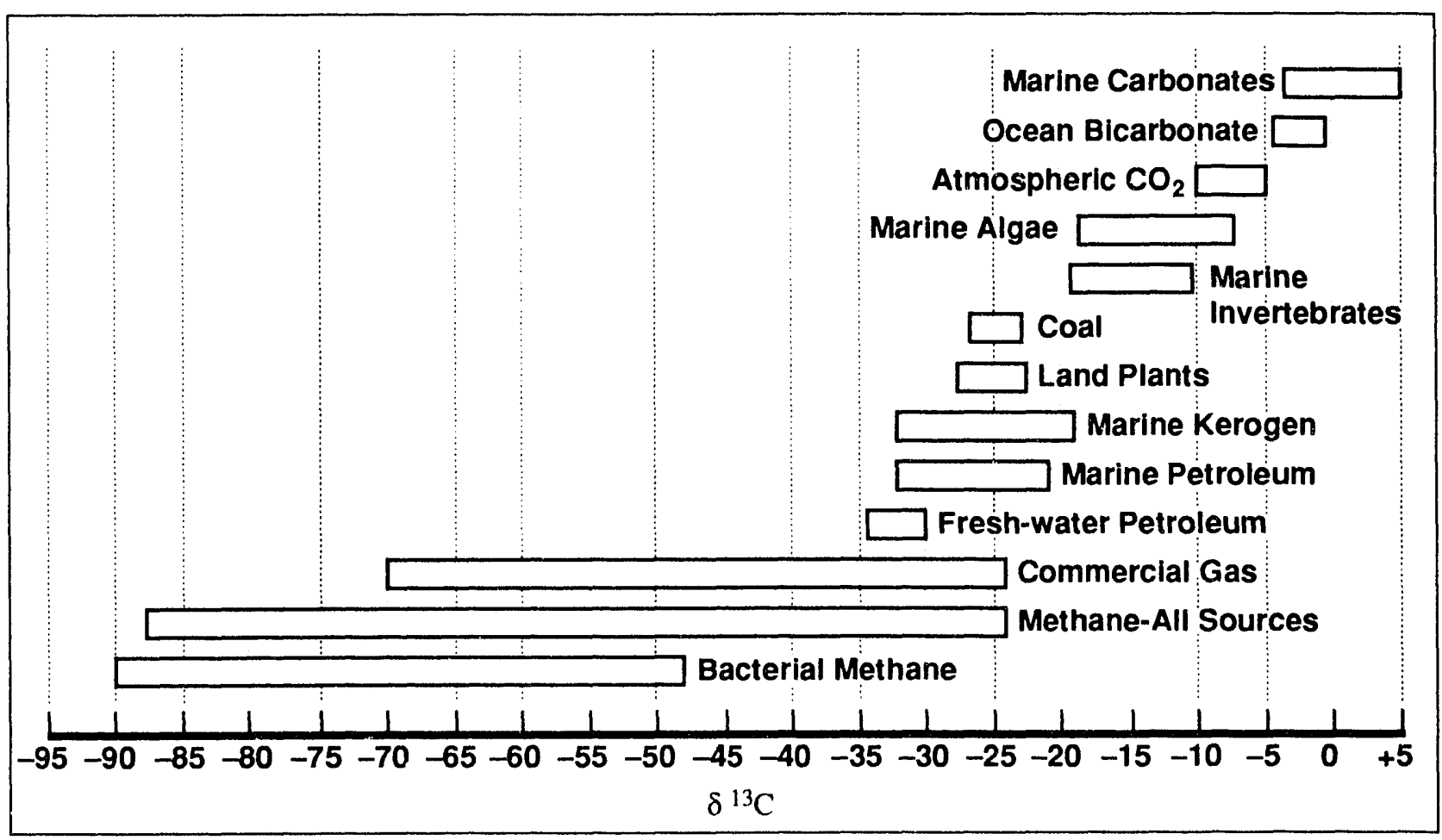

$6-S / 1152-01$

Figure 1. $\delta^{13} \mathrm{C}$ in various organic materials. 


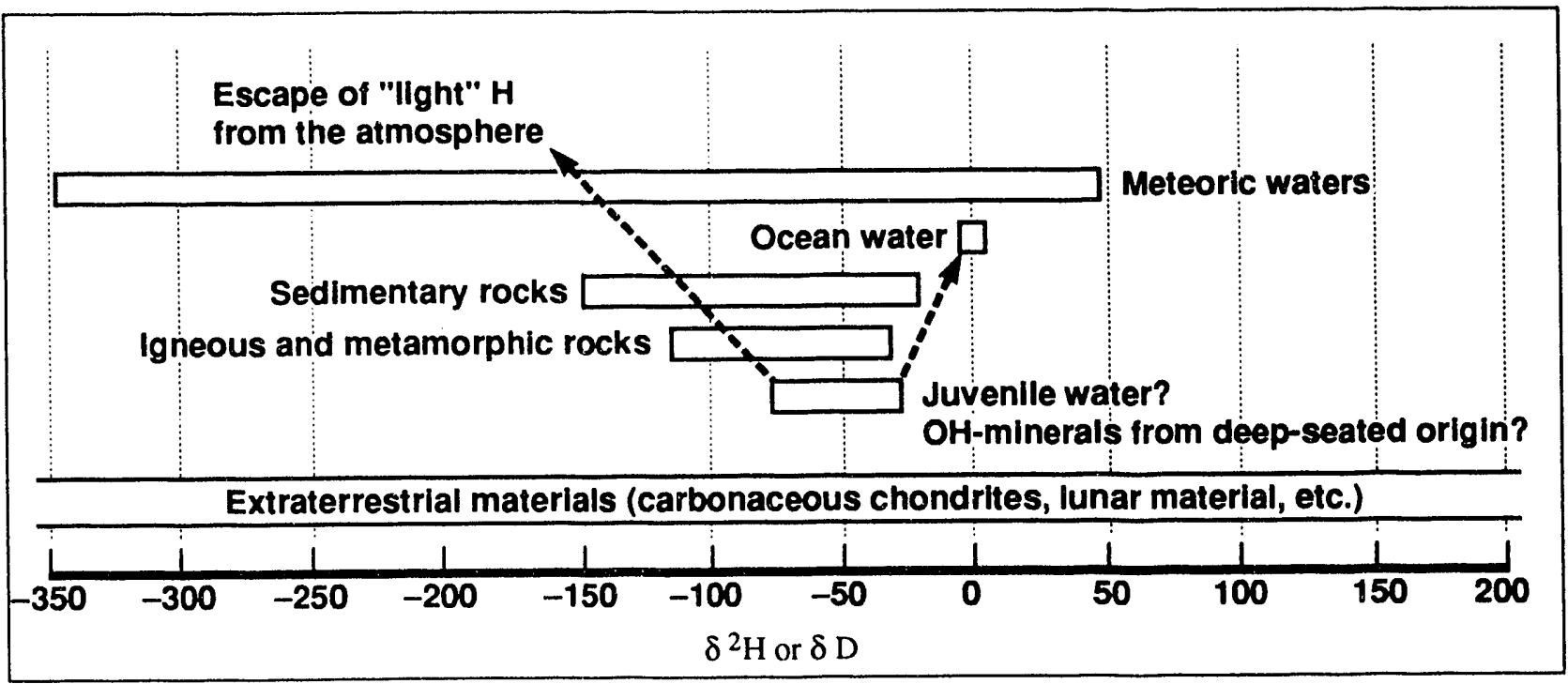

$6-S / 1152-02$

Figure 2. $D / H$ ratios of some important terrestrial compounds ( $\delta$-variations in $\%$ o0) relative to SMOW).

carbonate" called the PDB standard. Carbon " $\delta$ " values have been used successfully to:

- Distinguish fractionation effects for paleohydrologic investigations,

- Determine paleotemperatures,

- Gain information about carbon geochemistry of water, and

- Enhance geochemical prospecting.

Essentially all natural substances have a negative carbon $\delta$ (i.e., an isotopic composition that is lower in ${ }^{13} \mathrm{C}$ than the chosen standard).

The "delta" value for ${ }^{15} \mathrm{~N}$ is referenced to atmospheric nitrogen. Isotopic studies of terrestial nitrogen have been concerned primarily with biochemical reactions in soil to determine the sources of nitrogenous compounds in hydrologic systems. Studies to determine the origin of fossil fuels have also used nitrogen isotopes. The fractionation effects of nitrogen are not well understood. However, animal wastes and commercial fertilizers (nitrates) are the normal source of nitrogenous material in ground water. The " $\delta$ " value for ${ }^{15} \mathrm{~N} /{ }^{14} \mathrm{~N}$ increases with escaping ammonia.

The detonation of high explosives (HEs) results primarily in hot gaseous products. These products comprise the working fluid for the explosive application. However, most explosives also produce a solid residue or 
"soot" upon detonation. For nonmetallized explosives, this residue consists of nongraphitic carbon and poly-hydrocyano compounds. ${ }^{1}$

Greiner and Hermes have reported the isolation of carbon (diamond) from the collected residue of detonated explosives. ${ }^{2}$

McGuire et al. ${ }^{3}$, showed that the solid residue of ideal explosives contained the same isotopic ratio as the initial explosive within the limits of experimental measurement. This scenario was based on experiments with explosives labeled with stable isotopes $\left({ }^{13} \mathrm{C},{ }^{15} \mathrm{~N}\right.$, and ${ }^{18} \mathrm{O}$ ). (This was not the pattern for explosives that did not detonate ideally.) The configuration for the McGuire et al. experiments was different than the one discussed in this report. The McGuire et al. experiments were detonated in an evacuated vessel with no sources of soot other than the explosive being tested. Since those experiments were performed with explosives enriched in the rare isotopes, comparisons were made using absolute isotope concentrations rather than the "delta" system of references.

Based on this, we decided to investigate the possibility of determining the type and, perhaps, origin of explosives used for criminal activities from the ratios of the stable isotopes found in the explosive residue. To be effective, these ratios would have to be significantly different from one explosive to another and repeatable. Preliminary experiments performed in 1990 gave some indication that this might be the case. These 1990 data are not included in this report as the experimental details were sufficiently different that direct comparisons could not be made.

\section{EXPERIMENTAL DETAILS}

\section{Test Configuration}

The test configuration is shown in Fig. 3. The tests were fired inside a 4$\mathrm{ft}$-diameter, 2 -ft-tall steel cylinder with 1-in.-thick walls. To leave a gap, the cylinder was mounted on 3-in.-thick spacers on a 3-in.-thick aluminum plate. This gap allowed the force of the detonation to be dissipated while capturing the product soot on the walls and floor of the cylinder in a small enough area that it could be efficiently collected. A 3-in.-thick aluminum plate was placed on the top of the cylinder after the placement of the explosive charge. This plate was fitted with a connector to a vacuum cleaner with filters at the connector to the plate and at the connection to the vacuum cleaner itself. The entire assembly was placed inside a steel containment vessel in the test facility. 


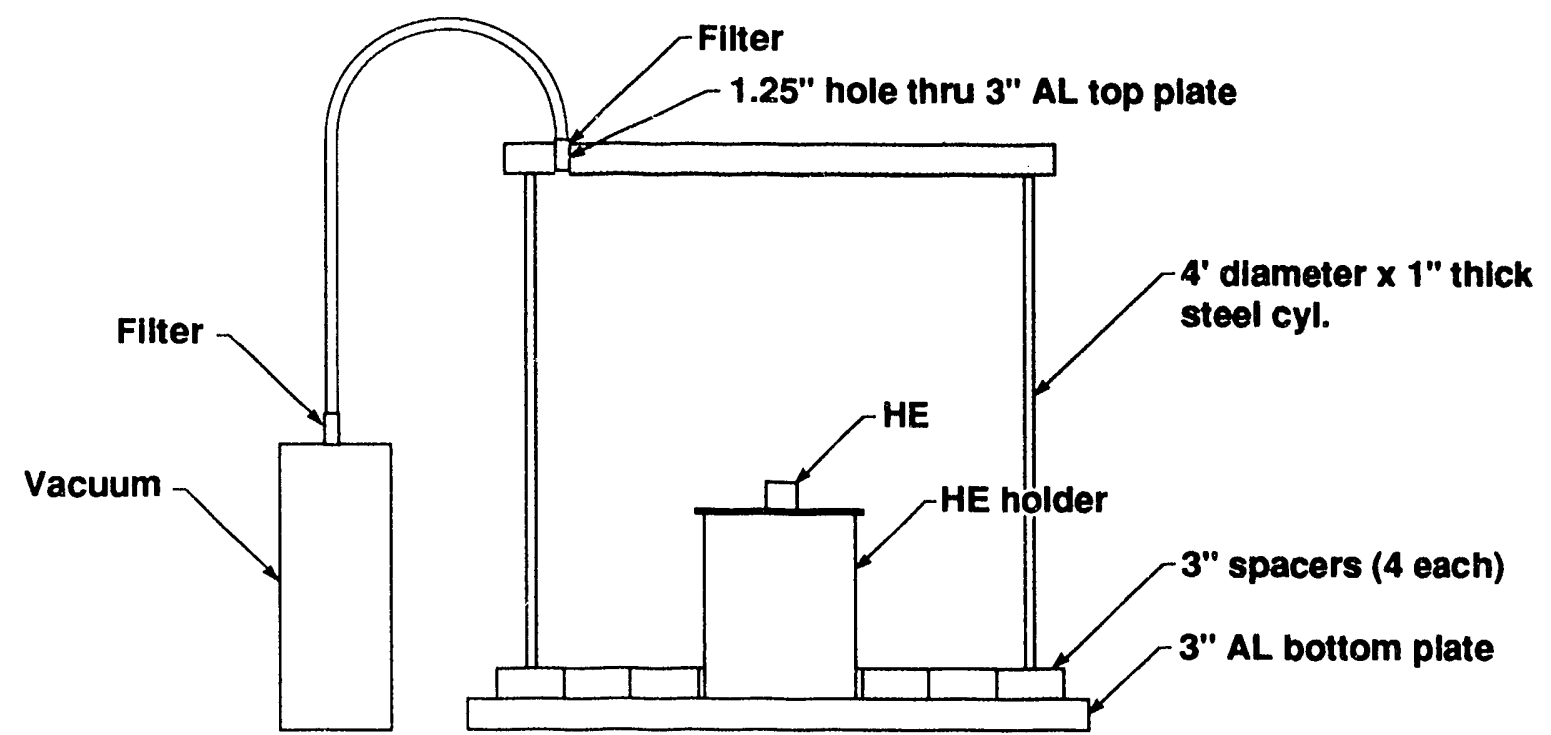

$6-S / 1152-03$

Figure 3. Experimental configuration.

The goal of the experimental design was to minimize the amount of extraneous organic material in each of the test detonations.

Unfortunately, it is practically impossible to totally eliminate sources of "soot" other than the explosive of interest. The charge must be firmly mounted with the detonator and a booster explosive if a complete detonation is to be assured. This, for safety reasons, is done with a cloth tape. The amount of cloth tape is kept to a minimum (on the order of a few grams). However, a small but unknown percentage of this tape contributes to the recovered products. In addition, the detonator contains a molded diallyl phthalate piece that, in all probability, becomes part of the recovered soot. Unfortunately, it was not possible to accurately determine the quantity of soot generated by each of the test explosives.

To minimize the effect of the contaminants:

1. We selected pentaerythritol tetranitrate (PETN) as the booster, because it did not contribute any "soot" to the products. (PETN is oxygen balanced to $\mathrm{CO}_{2}$ and has no solid residue). ${ }^{1}$ Between 2.8 and 3.0 grams of PETN was used as the booster for each test shot.

2. We used a small detonator (Reynolds-RP-2) containing only 0.6 grams of diallyl phthallate.

To minimize the possibility of cross contamination from one explosive shot to the next, we followed the procedure below:

1. We cleaned the inner surfaces of the cylindrical container after each shot, using isopropanol. 
2. We fired the experiments beginning with the explosives that produced the least soot and ending with those that produced the most.

3. After approximately every five tests, we fired a booster only shot to determine if soot was building up in the cylinder. The recovered soot from these tests was also analyzed for isotopic ratios.

4. We selected approximately 50 grams of test explosive (about 25 times the amount of other organic material).

\section{Selection of Explosives}

We selected explosives that would highlight different molecular structures and different manufacturing techniques. As stated earlier, PETN was used as the booster in all test shots because it did not contribute any solid residue. Other explosives selected are listed in Table 1. Figure 4 gives the molecular structure of each of these explosives.

The explosive charges were produced by hot pressing the sample material to greater than $97 \%$ of theoretical maximum density. Two 25 gram charges, stacked one on the other, were used in each test shot.

\section{Sample Analysis}

The samples were collected primarily from the vacuum cleaner filter ${ }^{4}$ by either brushing them off with a sable artist's brush or by ultrasonication in methanol. There was no detectable difference in the $\delta$ values as a result of the separation method used. The soot samples were then submitted for isotopic determination. ${ }^{5}$ Samples of the undetonated explosives were submitted along with the soot samples. The results are given in Table 2. 
Table 1. Explosives selected for experimental testing.

\begin{tabular}{ll}
\hline Explosive & \multicolumn{1}{c}{ Description } \\
\hline HMX & $\begin{array}{l}\text { A CO balanced, cyclic nitramine, containing aliphatic } \\
\text { carbon, originally derived from formaldehyde, ammonia and } \\
\text { nitric acid, giving a relatively small amount of soot. Acetic } \\
\text { anhydride is used in the production of HMX at the Holsten } \\
\text { Army Ammunition Plant, Kingsport, TN. }\end{array}$
\end{tabular}

LX-10 A plastic-bonded explosive consisting of HMX with $5 \%$ of a fluorocarbon binder, "Viton". a

LX-14 A plastic-bonded explosive consisting of HMX with $5 \%$ of a polyurethane binder, "Estane". Along with $L X-10$, this was used to examine the effects of various binders.

TNT Trinitrotoluene, an aromatic explosive derived from toluene and nitric acid giving a large amount of soot. Sulfuric acid is used in the production of TNT.

OCTOL An explosive consisting of $75 \% \mathrm{HMX}$ with $25 \%$ TNT. OCTOL was tested to see if the soot showed any compositional effects.

TATB Triamino trinitrobenzene, an aromatic explosive derived from benzene, ammonia, and nitric acid. Chlorine and sulfuric acid are used in all TATB production processes. Toluene and water are used in the "wet" amination process, toluene alone in the "dry" amination process. TATB from both processes and from three different manufacturers was tested to investigate the effect of processing. ${ }^{c}$

LX-17 A plastic-bonded explosive consisting of TATB with $7.5 \%$ of the chlorofluorocarbon binder KeL-F 800. ${ }^{d}$ Two samples of $L X-17$ were tested, produced by two formulators though both were from wet aminated TATB: Holsten Army Ammunition Plant, and the Pantex Plant of the Mason and Hanger, Silas Mason Co.

a Viton is a copolymer of vinylidene fluoride and perfluoropropylene, produced by E.I. du Pont.

b Estane is a polyester polyurethane, originally produced by the B.F. Goodrich Co. The LX-14 was produced by the Holsten Army Ammunition Plant, Kingsport, TN.

c Dry aminated TATB was produced by Rocketdyne Corp., Canoga Park, CA; wet aminated TATB samples were produced by the Aerojet General Corp., Sacramento, $\mathrm{CA}$, and by Mason and Hanger, Silas Mason Co. Pantex Plant, Amarillo, TX.

d $\mathrm{Kel}-\mathrm{F}$ is a copolymer of chlorotrifluoroethylene and vinylidene fluoride manufactured by $3 \mathrm{M}$ Corp. 
Table 2. Delta values for $C, H$, and $N$ in soot from detonation experiments.

\begin{tabular}{|c|c|c|c|c|}
\hline $\begin{array}{l}\text { Soot } \\
\text { Sample }\end{array}$ & $\begin{array}{l}\delta C\left({ }^{13} \mathrm{C} /{ }^{12} \mathrm{C}\right) \\
(\text { prts } / 1,000)\end{array}$ & $\begin{array}{l}\delta \mathrm{H}\left({ }^{2} \mathrm{H} /{ }^{1} \mathrm{H}\right) \\
(\mathrm{prts} / 1,000)\end{array}$ & $\begin{array}{l}\delta \mathrm{N}\left({ }^{15} \mathrm{~N} / 1^{14} \mathrm{~N}\right) \\
(\mathrm{prts} / 1,000)\end{array}$ & $\begin{array}{l}\text { Shot no. } \\
\text { Pretype }\end{array}$ \\
\hline$H M X$ & -30.1 & -81 & 1.0 & $2 M$ \\
\hline$H M X$ & -29.5 & -72 & 6.5 & $3 M$ \\
\hline$H M X$ & -28.7 & -70 & 6.8 & $3 B$ \\
\hline$H M X$ & -28.2 & -64 & 2.3 & $3 \mathrm{BM}$ \\
\hline$H M X$ & -28.4 & -61 & 8.8 & 3BM \\
\hline LX-10 & -33.8 & -73 & 0.5 & $4 M$ \\
\hline$L X-10$ & -34.2 & -66 & 1.3 & $5 M$ \\
\hline LX-14 & -33.6 & -68 & -0.5 & $7 M$ \\
\hline$L X-14$ & -33.8 & -71 & -0.7 & $8 M$ \\
\hline OCTOL & -28.7 & -52 & 1.3 & $17 \mathrm{M}$ \\
\hline OCTOL & -29.0 & -5 & -- & $18 \mathrm{M}$ \\
\hline TNT & -27.2 & -56 & -8.1 & $20 M$ \\
\hline TNT & -27.3 & -49 & -5.3 & $21 M$ \\
\hline TATB PW & -28.2 & -75 & -6.7 & $15 B$ \\
\hline TATB PW & -28.1 & -78 & -5.3 & $16 \mathrm{~B}$ \\
\hline TATB AW & -27.3 & -82 & -6.6 & 25B \\
\hline TATB AW & -27.4 & -71 & -6.6 & $26 \mathrm{M}$ \\
\hline TATB RD & -25.1 & -58 & -11.9 & $23 M$ \\
\hline TATB RD & -26.0 & -66 & -8.4 & $23 B$ \\
\hline TATB RD & -26.0 & -61 & -10.0 & $24 B$ \\
\hline$L X-17 P$ & -27.3 & -85 & -8.0 & $10 \mathrm{~B}$ \\
\hline$L X-17 P$ & -27.2 & -81 & -6.7 & $11 B$ \\
\hline LX-17H & -28.2 & -77 & -7.7 & $12 \mathrm{~B}$ \\
\hline$L X-17 H$ & -28.0 & -94 & -5.4 & $13 B$ \\
\hline
\end{tabular}

ashot numbers are in the order fired. $B=B$ rushed, $M=F l o a t e d$ with methanol. 


$$
\begin{aligned}
\mathrm{CH}_{2}-\mathrm{O}-\mathrm{NO}_{2} \\
\mathrm{O}_{2} \mathrm{~N}-\mathrm{O}-\mathrm{CH}_{2}-\mathrm{C}-\mathrm{CH}_{2}-\mathrm{ONO}_{2} \\
\stackrel{\mathrm{C}}{\mathrm{C}} \mathrm{H}_{2}-\mathrm{O}-\mathrm{NO}_{2}
\end{aligned}
$$

Pentaerythritol tetranitate PETN<smiles></smiles>

Cyclo-1,3,5,7-tetranitro-1,3,5,7-tetraazocine HMX 6-S/1152-04

Figure 4. Structures of explosives investigated.<smiles>Cc1c([N+](=O)[O-])cc([N+](=O)[O-])cc1[N+](=O)[O-]</smiles>

Trinitrotoluene TNT<smiles>Nc1c([N+](=O)[O-])c(N)c([N+](=O)[O-])c(N)c1[N+](=O)[O-]</smiles>

1,3,5-triamino-2,4,6-trinitro benzene TATB

\section{RESULTS AND DISCUSSION}

\section{Carbon Isotoplc Ratios}

The results (Table 3 and Fig. 5) show a clear difference in the $\delta$ values for carbon between the aromatic-based explosives (TNT and TATB) and the nonaromatic explosives (PETN and HMX). The values for the aromatic HEs are approximately -27 or $-28 \delta^{13} \mathrm{C}$, and the values for the nonaroinatic HEs average between -41 and $-44 \delta$. The fact that the $\delta$ value for OCTOL is -38.1 supports the precision of the measurement. (Based on the composition and the values for HMX and T'NT, the value for OCTOL would be calculated to be $-39 \delta$.)

There is some indication that the trend carries over into the detonation product soot (Fig. 6), even though the difference in values between the aromatic and nonaromatic explosives is much smaller. The $\delta \mathrm{C}$ values for the aromatic explosives are essentially unchanged by the detonation process. (Compare the values for the original explosives in Table 3 with those of the residues in Table 2.) The $\delta C$ values for the HMX detonation product soot are somewhat less negative than the values for HMX itself. This effect may be the result of contamination by the soot formed from 
Table 3. Delta values for $C, H$, and $N$ in original explosives.

\begin{tabular}{lccc}
\hline $\begin{array}{l}\text { Explosive } \\
\text { Sample }\end{array}$ & $\begin{array}{c}\delta \mathrm{C}\left({ }^{13} \mathrm{C} /{ }^{12} \mathrm{C}\right) \\
(\mathrm{prts} / 1,000)\end{array}$ & $\begin{array}{c}\delta \mathrm{H}\left({ }^{2} \mathrm{H} /{ }^{1} \mathrm{H}\right) \\
(\mathrm{prts} / 1,000)\end{array}$ & $\begin{array}{c}\delta \mathrm{N}\left({ }^{15} \mathrm{~N} /{ }^{14} \mathrm{~N}\right) \\
(\mathrm{prts} / 1,000)\end{array}$ \\
\hline PETN & -41.5 & -48 & -9.9 \\
HMX & -43.5 & -35 & -2.8 \\
LX-10 & -42.3 & -29 & -2.8 \\
LX-14 & -40.5 & -25 & -4.3 \\
OCTOL & -38.1 & -61 & -1.9 \\
TNT & -27.4 & -89 & +5.1 \\
TATB PW & -28.3 & -123 & -8.7 \\
TATB AW & -28.1 & -108 & -9.2 \\
TATB RD & -23.8 & -72 & -16.0 \\
LX-17 P & -26.3 & -186 & -10.2 \\
LX-17 H & -29.0 & -142 & -10.5
\end{tabular}

aTATB and $L X-17$ are denoted as $P=P a n t e x, A=$ Aerojet, $R=$ Rocketdyne, $\mathrm{H}=$ Holsten, $\mathrm{W}=$ Wet aminated, and $\mathrm{D}=\mathrm{Dry}$ aminated.

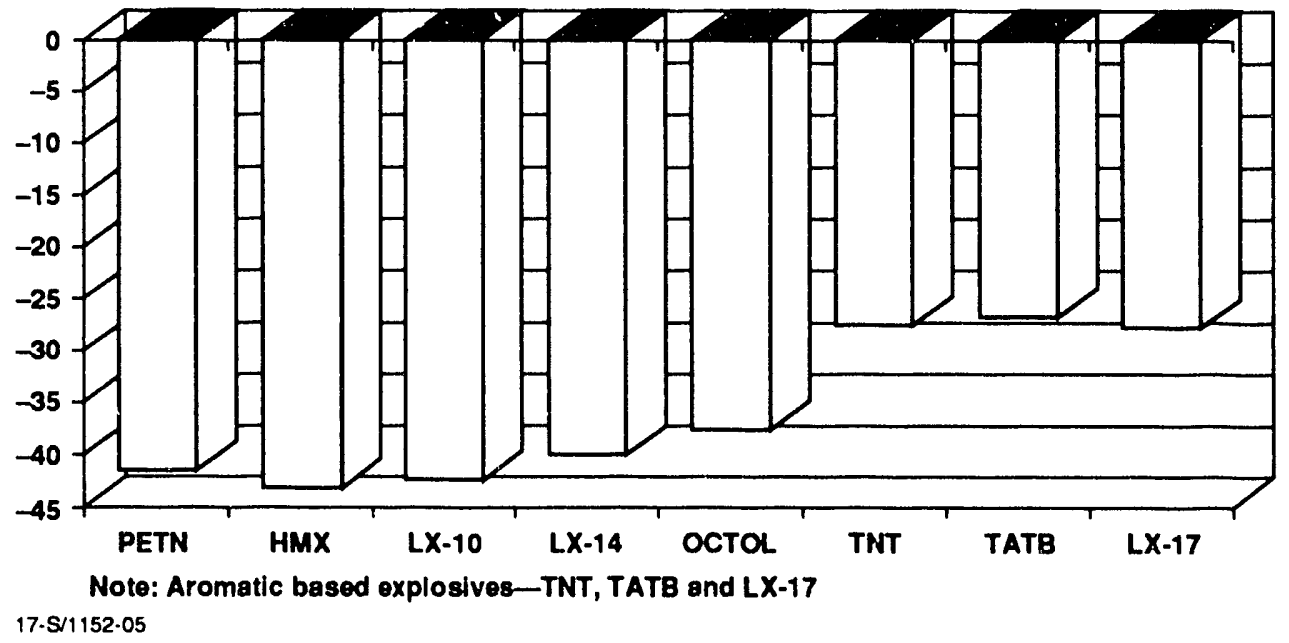

Figure 5. Carbon delta values for undetonated explosives. 


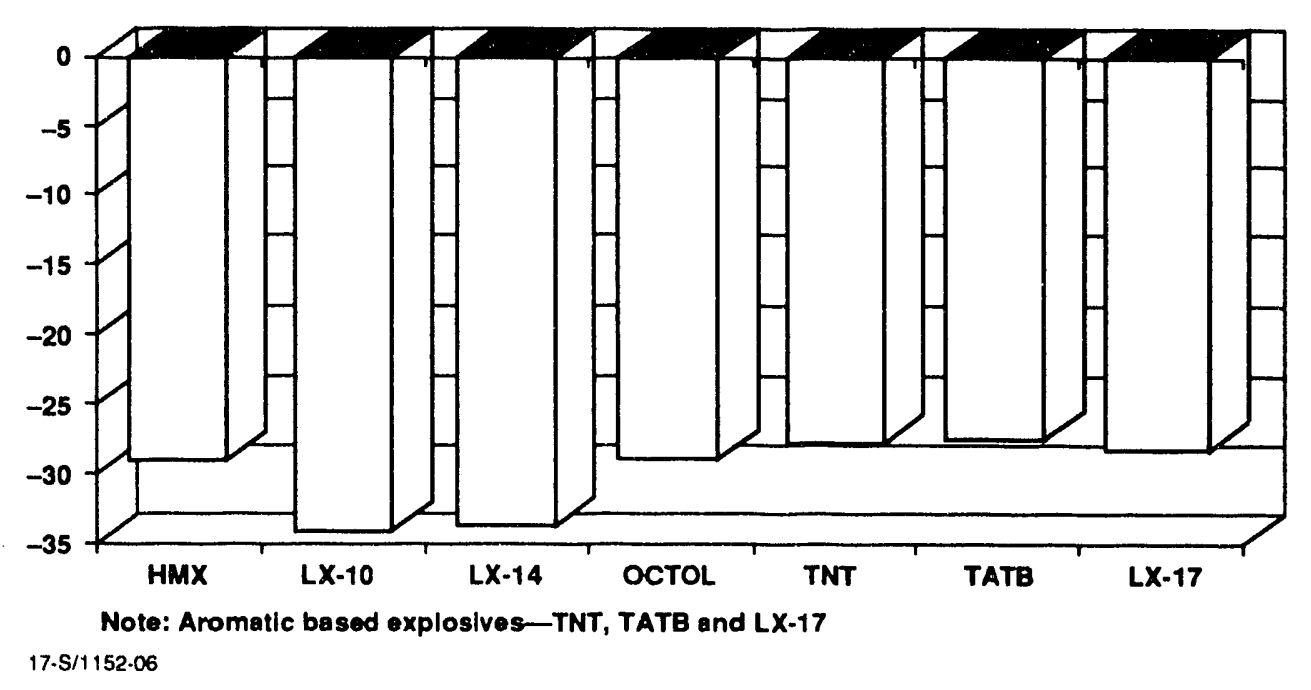

Figure 6. Carbon delta values for "soot" from detonated explosives.

the extraneous organic material in the shot if the soot from this "other" source is less negative than that from HMX. Contamination of the HMX products is more of a problem since there is significantly less soot produced by HMX than is produced by the aromatic HEs. The results from the booster only tests with $\delta$ values of -27 are consistent with the $\delta C$ values of the contaminants being less negative than the values for HMX. Thus, the "real $\delta$ " value for the HMX soot may be similar to that for HMX itself. The finding that isotopic ratios do not change for carbon between the explosive and its detonation products is consistent with previous work. (See Footnote 3.)

\section{Hydrogen Isotopic Ratios}

Trends in the $\delta \mathrm{H}$ values are similar to those seen in the $\delta \mathrm{C}$ values. In this case, however, the values are more negative for TNT $(-89 \delta)$ than for PETN and HMX ( -48 and $-35 \delta)$. The value for OCTOL is again intermediate, though not as good a fit with the calculated value as is the $\delta \mathrm{C}$ case. The values for TATB require special comment. The $\delta \mathrm{H}$ for dry aminated TATB is -72 while the values for the two samples of wet aminated TATB are -123 and $-108 \delta$. This difference undoubtedly reflects the isotopic exchange between the ammonia reagent and the water in the reaction medium. (Water can have very large negative $\delta \mathrm{H}$ values.) Similar exchange between ammonia and the toluene used for dry amination would be negligible. 
Unfortunately, these discernible differences do not seem to show up in the $\delta \mathrm{H}$ values for the detonation soots as there are larger differences in $\delta \mathrm{H}$ values between duplicate soot samples than there are between samples from different explosives. Hydrogen isotopes were not included in earlier detonation studies (see Footnote 3 ) because of a concern about the possibility of exchange during workup and analysis.

\section{Nitrogen Isotopic Ratios}

The interpretation of the $\delta \mathrm{N}$ values must be evaluated cautiously:

1. The mole percentage of nitrogen in the detonation product soots is small when compared to carbon and hydrogen. When this is coupled with the small amount of soot from the nonaromatic explosives, very little should be read into the results.

2. There is a great deal of scatter among the results of supposedly duplicate experiments and between values from samples of the same soot extracted by different techniques. (The data from the TNT and TATB explosives which give more product soot, while showing some scatter, are much better than that for the HMX HEs). As a result of these deficiencies in the data, the interpretation can only be considered as preliminary.

Nevertheless, certain trends are present that, if substantiated by further experiment, could be significant. Namely:

1. There is a definite trend for the $\delta \mathrm{N}$ values to become more positive upon detonation. Since the containment vessel was not evacuated, this result could indicate a reaction with atmospheric nitrogen prior to "freeze out" of the product soot. This trend seems to be consistent even in the HMX explosives where the data are uncertain.

2. Contrary to Item 1 , the $\delta \mathrm{N}$, for those explosives giving significant amounts of soot, is of the same sign $(+/-)$ and nearly the same value as the parent explosive.

3. The value of $\delta \mathrm{N}$ for the TATB explosives, the nitrogen in which is partially derived from ammonia, is negative; while the value for TNT, which has only nitrogen derived from nitric acid, is positive. 


\section{SUMMARY}

The detonation of a series of explosives was performed in a controlled manner to collect the resulting solid residue or "soot." This residue was examined to determine the ratios of the stable carbon, hydrogen, and nitrogen isotopes. The goal of the experiment was to determine if these ratios could be used to indicate, from the post detonation residues, the type and origin of the detonated explosive. The ratios of the stated stable isotopes in the undetonated explosive were also determined.

Despite some reservations in the quality of the data resulting from contamination by nonexplosive components, certain trends can be discerned.

1. Carbon isotopes allow aromatic explosives to be distinguished from nonaromatic explosives. This trend seems to carry through the detonation so that the distinction might be made after the fact.

2. The amination process for TATB can be detected through the hydrogen and, to some extent, the nitrogen isotope ratios. Unfortunately, the data are not sufficiently good to determine if this differential carries through the detonation.

3. The relative magnitude and sign of the nitrogen isotope ratio seems to carry through the detonation: some exchange with atmospheric nitrogen is probable.

Even though this set of experiments must also be viewed as preliminary, there is a definite indication that certain qualitative characteristics of explosives can be detected after the detonation. This "signature" could have application to both intelligence and counter terrorism.

\section{ACKNOWLEDGMENT}

The authors express their thanks to Mr. Tom Cook for his help in obtaining the explosive charges, to Ms. Rochelle Clements and Mr. Larry Crouch for their assistance in detonating the explosives. 


\section{REFERENCES}

1. McGuire, R. R. and D. L. Ornellas, Private communication; and D. L. Ornellas, Calorimetric Determinations of the Heat and Products of Detonation for Explosives: October 1961 to April 1982, Lawrence Livermore National Laboratory, UCRL-52821 (April, 1982).

2. Greiner, N. R. and R. Hermes, "Chemistry of Detonation Soot: Diamond, Graphite and Volatiles," Proceedings of the 8th International Symposium on Detonation, pp. 1170-75, Portland, OREG., 1989.

3. McGuire, R. R., D. L. Ornellas, and I. Akst, "Detonation Chemistry: Diffusion Control in Non-Ideal Explosives," Propellants and Explosives, 4, 23-26 (1979).

4. Part 901-01, Shop-Vac Corporation, Williamsport, PA.

5. Isotopic analyses were performed by Krueger Enterprises, Inc., Geochron Laboratories Div., Cambridge, MA. 

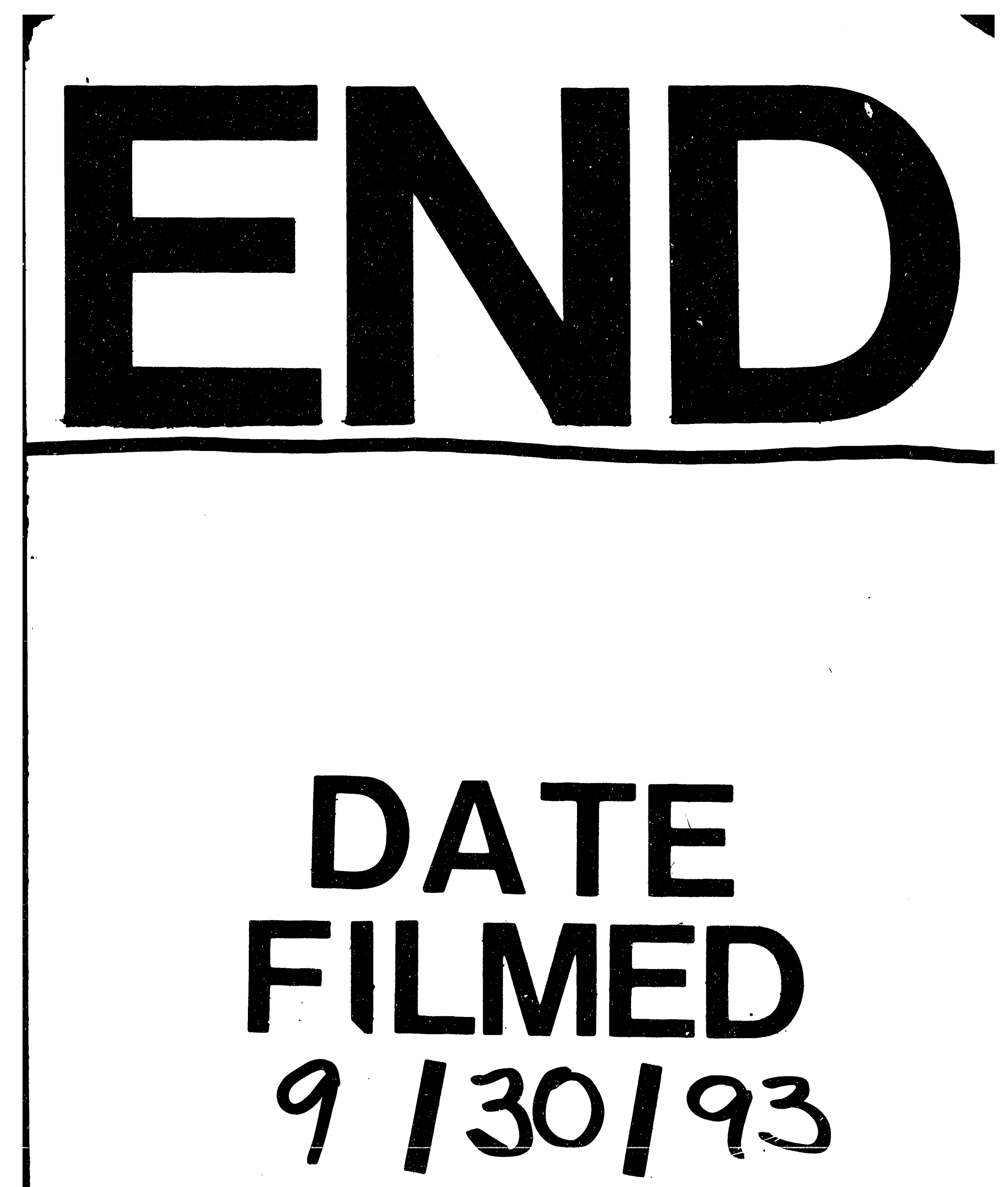
